\title{
PEDOLOGICAL AND ISOTOPIC RELATIONS OF A HIGHLAND TROPICAL PEATLAND, MOUNTAIN RANGE OF THE ESPINHAÇO MERIDIONAL (BRAZIL) ${ }^{(1)}$
}

\author{
Ingrid Horák ${ }^{(2)}$, Pablo Vidal-Torrado ${ }^{(3)}$, Alexandre Christófaro \\ Silva $^{(4)} \&$ Luiz Carlos Ruiz Pessenda ${ }^{(5)}$
}

\begin{abstract}
The evolution of organic matter sources in soil is related to climate and vegetation dynamics in the past recorded in paleoenvironmental Quaternary deposits such as peatlands. For this reason, a Histosol of the mineralotrophic peatland from the Pau-de-Fruta Special Protection Area - SPA, Espinhaço Meridional, State of Minas Gerais, was described and characterized to evidence the soil constituent materials and properties as related to changes in environmental conditions, supported by the isotopic and elementary characterization of soil $\mathrm{C}$ and $\mathrm{N}$ and ${ }^{14} \mathrm{C}$ ages. Samples were collected in a depression at $1,350 \mathrm{~m}$ asl, where Histosols are possibly more developed due to the great thickness $(505 \mathrm{~cm})$. Nowadays, the area is colonized by vegetation physiognomies of the Cerrado Biome, mainly rocky and wet fields (Campo Rupestre and Campo Úmido), aside from fragments of Semidecidual Seasonal Forest, called Capões forests. The results this study showed that early the genesis of the analyzed soil profile showed a high initial contribution of mostly herbaceous organic matter before $8,090 \pm 30$ years $\mathrm{BP}\left({ }^{14} \mathrm{C}\right.$ age $)$. In the lower-mid Holocene, between $8,090 \pm 30$ years $\mathrm{AP}\left({ }^{14} \mathrm{C}\right.$ age $)$ to $\pm 4,100$ years $\mathrm{BP}$ (interpolated age), the vegetation gradually became more woody, with forest expansion, possibly due to increased humidity, suggesting the existence of a more woody Cerrado in the past than at present. Drier climate conditions than the current were concluded $\pm 2,500$ years $B P$ (interpolated age) and that after 430 years BP $\left({ }^{14} \mathrm{C}\right.$ age) the forest gave way to grassland, predominantly. After the dry season, humidity increased to the current conditions. Due to these climate
\end{abstract}

\footnotetext{
(1) Parte da dissertação de mestrado do primeiro autor, apresentada ao Programa de Pós-Graduação Solos e Nutrição de Plantas, Escola Superior de Agricultura "Luiz de Queiroz" - ESALQ/USP. Received for publication in December 2009 and approved in September 2010.

(2) Pós-Graduanda do Programa de Pós-Graduação Solos e Nutrição de Plantas, Escola Superior de Agricultura "Luiz de Queiroz" - ESALQ/USP. Caixa Postal 9, Av. Pádua Dias 11, CEP 13.418-900 Piracicaba (SP). E-mail: ihorak@esalq.usp.br

(3) Professor Titular do Departamento de Ciência do Solo, ESALQ/USP. E-mail: pablo@esalq.usp.br

(4) Professor Adjunto do Departamento de Engenharia Florestal, Universidade Federal dos Vales do Jequitinhonha e Mucuri UFVJM. Caixa Postal 38, CEP 39100-000 Diamantina (MG). E-mail: alexandre.christo@ufvjm.edu.br

(5) Professor Associado do Centro de Energia Nuclear na Agricultura - CENA/USP. Caixa Postal 96, Av. Centenário 303, CEP 13400970 Piracicaba (SP). E-mail: pessenda@cena.usp.br
} 
fluctuations during the Holocene, three decomposition stages of organic matter were observed in the Histosols of this study, with prevalence of the most advanced (sapric), typical of a deposit in a highly advanced stage of pedogenetic evolution.

Index terms: Paleoenvironmental reconstruction, decomposition of organic matter, pedogenesis of Histosols, climate changes, sapric soils.

\title{
RESUMO: RELAÇÕES PEDOLÓGICAS E ISOTÓPICAS DE UMA TURFEIRA NA SERRA DO ESPINHAÇO MERIDIONAL - MG
}

\begin{abstract}
A evolução das fontes de matéria orgânica no solo está relacionada com a dinâmica do clima e da vegetação durante épocas passadas, representadas pelos registros paleoambientais em depósitos quaternários como as turfeiras. Por esta razão, um organossolo da turfeira mineralotrófica da Área de Proteção Especial - APE Pau-de-Fruta, Serra do Espinhaço Meridional, MG foi descrito e caracterizado com a finalidade de evidenciar os materiais constituintes e os atributos do solo relacionados às mudanças das condições do ambiente, apoiados pela caracterização isotópica e elementar do $\mathrm{Ce} \mathrm{N}$ do solo e idades ${ }^{14} \mathrm{C}$. A amostragem foi realizada em uma depressão localizada a $1.350 \mathrm{~m}$ de altitude, onde possivelmente os Organossolos são mais desenvolvidos, devido à elevada espessura de $505 \mathrm{~cm}$. A turfeira atualmente é colonizada por fisionomias vegetais do Bioma Cerrado, principalmente Campo Rupestre e Campo Úmido, além de alguns redutos de ilhas de Floresta Estacional Semidecidual, denominados Capões de Mata. Os resultados deste estudo demonstraram que a gênese inicial do perfil de solo estudado, antes de $8.090 \pm 30$ anos $A P$ (idade ${ }^{14} \mathrm{C}$ ), apresentou elevada contribuição de uma matéria orgânica mais herbácea, e gradualmente no Holoceno Inferior / Médio, entre $8.090 \pm 30$ anos $A P\left(\right.$ idade $\left.{ }^{14} C\right) a \pm 4.100$ anos AP (idade interpolada), a vegetação tornou-se mais lenhosa, com expansão de uma mata, possivelmente devido ao aumento de umidade, sugerindo a existência no passado de um Cerrado mais lenhoso que o atual. Condições de um clima mais seco que o atual foi verificado em \pm 2.500 anos AP (idade interpolada) $e$ após 430 anos $A P\left(\right.$ idade $\left.{ }^{14} C\right)$, quando a mata regrediu, predominando a vegetação de campo. Após o período mais seco, a umidade aumentou até as condições atuais. Em meio a essas flutuações climáticas durante o Holoceno, o Organossolo em estudo apresentou três estádios de decomposição da matéria orgânica, com predomínio do mais avançado (sáprico), característico de um depósito em estágio de evolução pedogenético altamente avançado.
\end{abstract}

Termos de indexação: Reconstrução paleoambiental, decomposição da matéria orgânica, pedogênese de Organossolo, mudanças climáticas, solos sápricos.

\section{INTRODUCTION}

High water contents in the soil, high acidity, lack of oxygen, low redox potential and the inhibitory effect of organic acids favor the accumulation of organic material and the formation of peatlands. In the Mountain Range of the Espinhaço Meridional, peatlands occur in flat-surfaced depressions, covered with Campo Rupestre and Campo Úmido vegetation, and are related to endemic biodiversity, $\mathrm{C}$ storage, and water volume and quality in the region.

Histosols have been used in studies on the evolution of landscapes due to climate change, since they contain natural preserved paleoenvironmental records within the Quaternary organic deposits (Mauquoy \& Yelloff, 2008). Evidences of past conditions are represented by charcoal fragments (Pessenda et al., 2004), plant fragments (Spielhagen \& Tripati, 2009), sand deposition (Jianli et al., 1999), fossil plants and animals (Salgado-Labouriau, 2007), besides revealing the quantity, size and thickness of plant fibers (Ledru et al., 1996), color and soil consistency (Fitzpatrick et al., 2009).

The isotopic technique $\left(\delta^{13} \mathrm{C}\right)$ associated with the ${ }^{14} \mathrm{C}$ soil age is widely used for the reconstitution of paleovegetation (Pessenda et al., 2004, 2005b). The application of isotope ${ }^{13} \mathrm{C}$ is based on the difference of the isotopic signal of the $\mathrm{C}_{3}$ photosynthetic group of plants (typical of forest trees) and $\mathrm{C}_{4}$ photosynthetic group (typical vegetation of open fields), and can therefore be used to determine the origin of organic material in the soil, and then, inferences regarding vegetation can be made. Contents of $\delta^{13} \mathrm{C}$ in $\mathrm{C}_{3}$ plants range from about -35 to $-22 \%$ (average $-27 \%$ ). In contrast, contents of $\delta^{13} \mathrm{C}$ in $\mathrm{C}_{4}$ plants vary from $16 \%$ to $-9 \%$ (average $-13 \%$ ). Therefore, $\mathrm{C}_{3}$ and $\mathrm{C}_{4}$ have distinct $\delta^{13} \mathrm{C}$ values and differ by about $14 \%$ (Pessenda et al., 2004).

Nitrogen isotopes and the nitrogen and carbon concentration, in particular $\delta^{15} \mathrm{~N}$ and $\mathrm{C} / \mathrm{N}$ ratio, 
complement the information obtained by $\delta^{13} \mathrm{C}$, underlying the evaluation of both the terrestrial and aquatic sources of the organic material involved. Elevated ${ }^{15} \mathrm{~N}$ values indicate the predominance of algae (+8.5\%), while low values suggest the predominance of terrestrial plants (+0.5\%) (Peterson \& Howarth, 1987). Low C/N ratio (4 and 10) indicates the presence of organic matter from algae and phytoplankton, whereas high ratio (greater than or equal to 20) indicates terrestrial plants (Talbot \& Johannessen, 1992).

The hypothesis presumes that the histosols of peatlands from the Pau-de-Fruta Special Protection Area - SPA, Espinhaço Southern - MG are a record of temporal and spatial dynamics of vegetation and climate, due to high carbon content and an environment anoxic. Thus, it was aimed to pedologically describe and characterize a histosol of this peatland and analyze the elemental and isotopic composition of carbon and nitrogen in order to identify the sources of the organic material and the dynamics of soil formation.

\section{MATERIAL AND METHODS}

\section{Study area}

The study was conducted in a Histosol profile of the peatland in the Pau-de-Fruta Special Protection Area - SPA, Espinhaço Meridional - MG, 6 km away from the municipality of Diamantina, Minas Gerais (Figure 1), at altitudes of 1,300-1,370 $\mathrm{m}$ and an average annual rainfall of $1,437 \mathrm{~mm}$ (Neves et al., 2005). The average annual temperature is $18.70^{\circ} \mathrm{C}$,

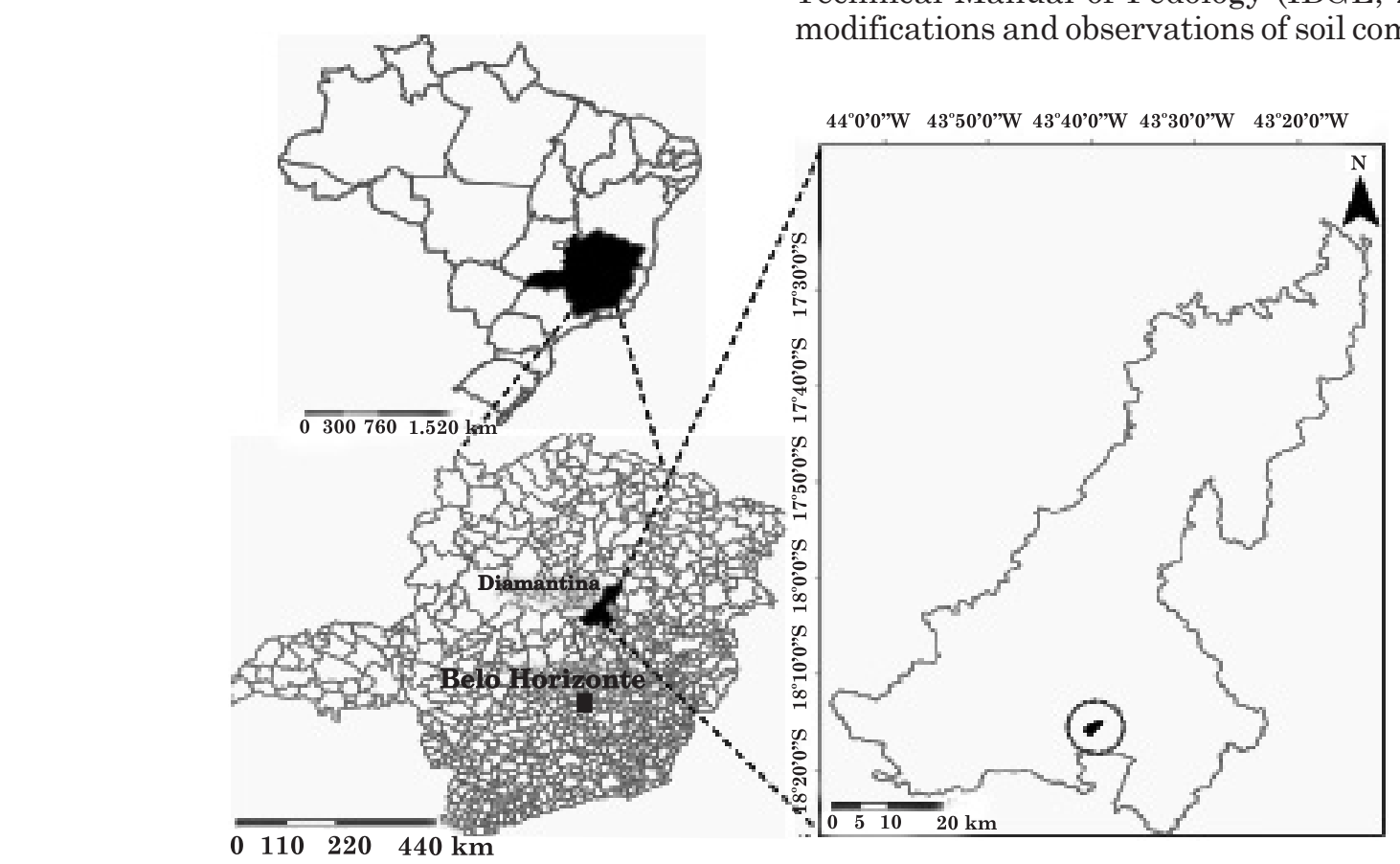

the winters from June to August cold and dry and the summers from October to April mild and wet. The predominant climate is mesothermal (Cwb) (Köppen classification).

Of the 1,700 ha of the protected area, 81.75 ha are occupied by peatland Histosols (Campos, 2009), and on the edges, these soils are associated with Entisol Quartzipsamments. This is the environment of the headwaters of the Córrego das Pedras stream, the water supply of the population of Diamantina (MG) and of endemic flora and fauna.

The vegetation in Pau-de-Fruta SPA is mosaic, i.e., the Semidecidual Seasonal Forest, called Capões forest (Veloso et al., 1991; Veloso, 1992), located in the midst of the Cerrado (Ribeiro \& Walter, 1998), includes savanna (Cerrado Típico, Cerrado Ralo and Cerrado Rupestre) and forest formations (Cerradão) and grasslands (Campos Limpo and Campo Rupestre).

\section{Soil sampling and description}

A prospection was conducted to identify the thickest part of the bog to choose the sampling location, taking into account the fact that thicker deposits may contain a greater quantity of records.

The Histosol profile with a thickness of $505 \mathrm{~cm}$ (18 ${ }^{\circ} 15^{\prime} 27.08^{\prime} \mathrm{S} ; 43^{\circ} 40^{\prime} 3.64$ " W; $1,350 \mathrm{~m}$ asl) was collected using a vibro-corer (Martin et al., 1995).

The undisturbed soil monolith was transported to the laboratory of the Federal University of the Jequitinhonha and Mucuri Valleys (UFVJM) where the collection tube was opened and the soil pedologically described according to the Manual of Field Soil Description and Collection (Santos et al., 2005) and Technical Manual of Pedology (IBGE, 2005), with modifications and observations of soil composition.

Figure 1. Location of the peatland from Pau-de-Fruta SPA. 
Forty-three soil samples were collected at intervals of about $10 \mathrm{~cm}$, except in $60-137 \mathrm{~cm}$ due to the presence of a water layer, cool-stored and sent to the laboratory of the Soil Science Department of the College of Agriculture "Luiz de Queiroz" (ESALQ/USP) for characterization of soil pedological properties and sample preparation for elemental and isotopic analyses of carbon and nitrogen.

\section{Analytical determinations}

The $\mathrm{pH}$ and $\mathrm{Eh}$ of the soil solution were determined with the still undisturbed profile, prior to the removal of the 43 samples. The $\mathrm{pH}$ was determined with a portable HANNA Instruments electrode, previously calibrated with standard $\mathrm{pH} 4$ and 7, and the Eh, by a platinum electrode, HANNA Instruments ORP model (values corrected by adding the value of the reference potential of the respective hydrogen standard electrode, $244 \mathrm{mV}$ ).

The decomposition stages of organic matter were determined on the von Post scale of decomposition (Stanek \& Silc, 1977) described by Embrapa (2006). The color by sodium pyrophosphate $\left(\mathrm{Na}_{2} \mathrm{P}_{2} \mathrm{O}_{7}\right)$, rubbed fiber (RF), unrubbed fiber (URF), gravimetric moisture $(\mathrm{Gm})$, minimal residue (MR), mineral material (MM), bulk density (Bs), organic matter density (Omd), $\mathrm{pH}$ in $\mathrm{CaCl}_{2}$, and organic matter content (OM) were determined according to the characterization tests of Histosols (Embrapa, 2006).

The elemental and isotopic analyses of soil $\mathrm{C}$ and $\mathrm{N}$ (total organic carbon - TOC, N, C/N ratio, $\delta^{13} \mathrm{C}$ and $\delta^{15} \mathrm{~N}$ ) were performed at the Laboratory of Stable Isotope of the Center of Nuclear Energy in Agriculture (CENA/USP) in an elemental analyzer coupled to a ANCA-SL 2020 mass spectrometer, Scientific Europa.

Of the 43 samples, four were selected for the ${ }^{14} \mathrm{C}$ analysis by the AMS technique (Accelerator Mass Spectrometry) at the AMS Laboratory at the University of Georgia (UGAMS) - Georgia/USA. The results were corrected to the natural isotopic fractionation $(-25 \%)$ and presented at conventional age expressed in ${ }^{14} \mathrm{C}$ years $\mathrm{BP}(1$ sigma $)(\mathrm{BP}=$ years before present, which is equal to 1950).

\section{Statistical analysis}

The soil property data for soil characterization were discussed based on a statistical analysis of simple and multivariate correlation using SPSS 17.0 and SAS 9.1, respectively. The resulting matrix of the Pearson correlation analysis was used to evaluate the degree of correspondence among the analyzed properties. The Draftsman representations, derived from multivariate analysis, were used to analyze the distribution of morphological, physical and chemical properties with depth, whereas the Biplot graph, dispersion of scores in the first two principal components (PCA), was used to verify which of the tested properties for Histosol characterization contributed most to soil formation and which best discriminated layers/horizons in this study.

\section{RESULTS AND DISCUSSION}

\section{Description of soil and ${ }^{14} \mathrm{C}$ ages}

The Histosol profile at $505 \mathrm{~cm}$ consisted of 13 horizons of which the first 10 are histic horizons $(\mathrm{H}$ horizon) containing organic material and the other three are sandy $\mathrm{C}$ horizons (Figure 2).

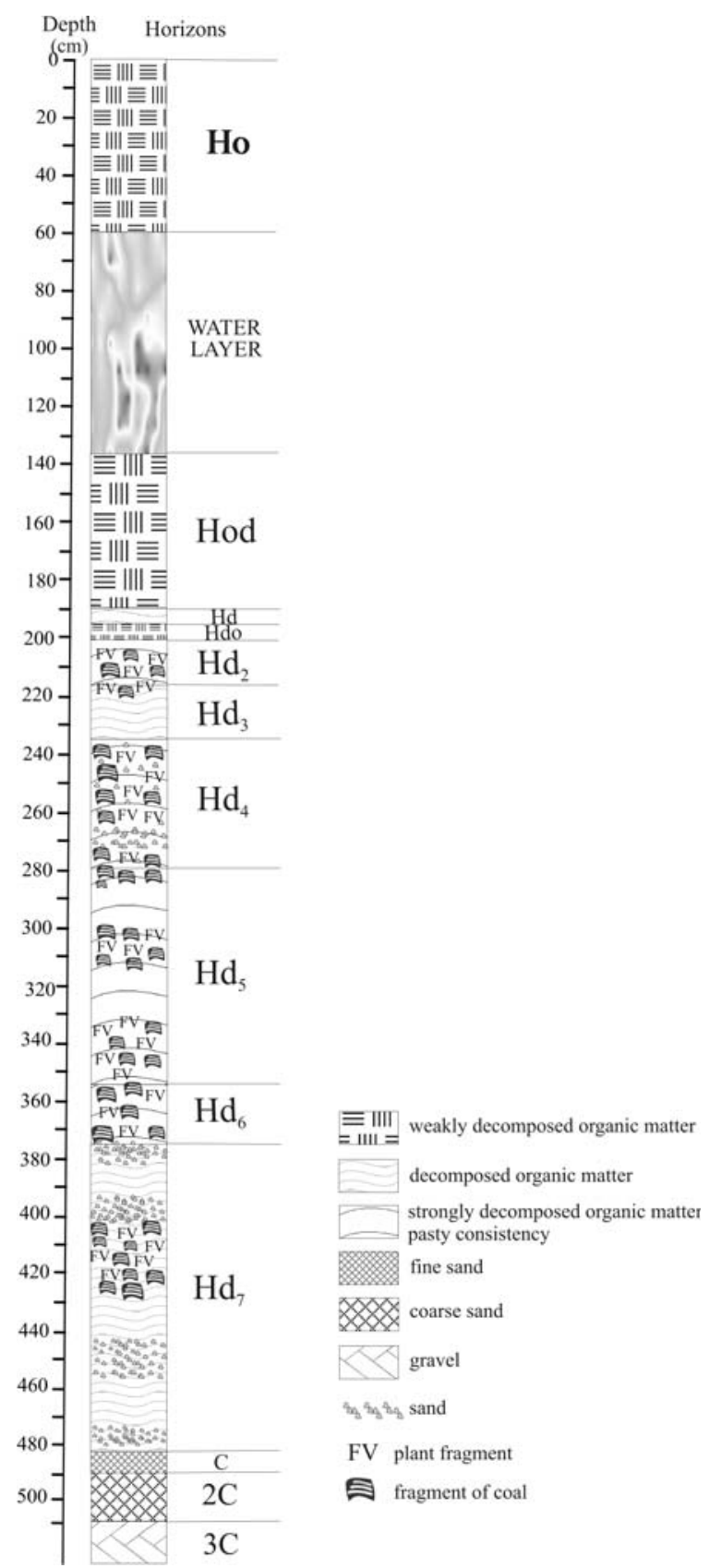

Figure 2. Representative diagram of the horizon distribution in the profile of the peatland from Pau-de-Fruta SPA. 
The base is composed of gravel and sand and there is a water layer with a small amount of very viscous organic material between 60-137 cm, explained by the hypothesis of a collapse of one of the layers, as proposed by Clymo (1992) for the structural model of peatlands. In this model, the surface layer, called the euphotic layer, shows the photosynthetic activity of vegetation, while in the underlying layer, the plant material is decomposing and soil porosity and hydraulic conductivity are high. Due to pressure exerted by the water weight of the upper levels, the third layer collapses, resulting in a sharp increase in density in the base besides the predominance of lateral flow and accumulation of a more organic material. In the last layer, called layer of anaerobic decomposition, the density is high, hydraulic conductivity low and anoxia permanent.

Other authors established different hypotheses for the formation of water layers. Boatman \& Tomlinson (1973) in Scotland, and Barber (1981) in the Netherlands related this formation to climate change, shifting from a drier to a more humid condition, in which hydraulic conductivity decreased and the humidification of peat was inhibited. Foster \& Fritz (1987) in Sweden explained the reduction of peat accumulation rate as a result of vegetation change from a stratum consisting of Scirpus and Eriophorum (Cyperaceae) to a layer of Sphagnum (Bryophyta).

The genesis of the studied peatland began around $8,090 \pm 30$ year BP, which is the age attributed near the profile base (Table 1).

No reversal of the ${ }^{14} \mathrm{C}$ ages was observed, since the chronology followed the trend of oldest at the bottom to youngest at surface. The highest recovering rate was observed in $167-172 \mathrm{~cm}, 0.33 \mathrm{~cm}$ year $^{-1}$. The
Table $1 .{ }^{14} \mathrm{C}$ dating of the peatland profile from Paude-Fruta SPA

\begin{tabular}{|c|c|c|c|}
\hline Depth & ${ }^{14} \mathrm{C}$ Age & Recovering rate & Sedimentation rate \\
\hline $\mathrm{cm}$ & years BP & $-\mathrm{cm}$ & year $^{-1}$ \\
\hline $55-60$ & $430 \pm 25$ & 0.13 & 1.54 \\
\hline $60-137$ & & Water layer & \\
\hline $167-172$ & $500 \pm 25$ & 0.33 & 0.033 \\
\hline $289-294$ & $4,030 \pm 30$ & 0.072 & 0.045 \\
\hline $475-481$ & $8,090 \pm 30$ & 0.059 & \\
\hline
\end{tabular}

highest sedimentation rate occurred above the water layer in $55-60 \mathrm{~cm}$, with $1.54 \mathrm{~cm}_{\text {year }}{ }^{-1}$, probably due to less humid weather conditions, with possible vegetation changes, such as density reduction and/or replacement of species with high contribution of organic matter by others with less. When the vegetation cover is poor, any precipitation may cause severe erosion, with subsequent transport of soil minerals to the sedimentary basin and a probable increase in the sedimentation rate (Bertaux et al., 1996).

Interpolated ages of the profile depths can be obtained between the ${ }^{14} \mathrm{C}$ ages following straight lines (Figure 3).

The age difference between the depth intervals below and above the water layer, respectively, 167$172 \mathrm{~cm}$ and $55-60 \mathrm{~cm}$, of only 70 years (Table 1; Figure 3), shows a very short time space to fill $77 \mathrm{~cm}$. This reinforces the hypothesis of a structural collapse.

Charcoal fragments, plant fragments and sand deposition were observed in the $200-375 \mathrm{~cm}$ horizons

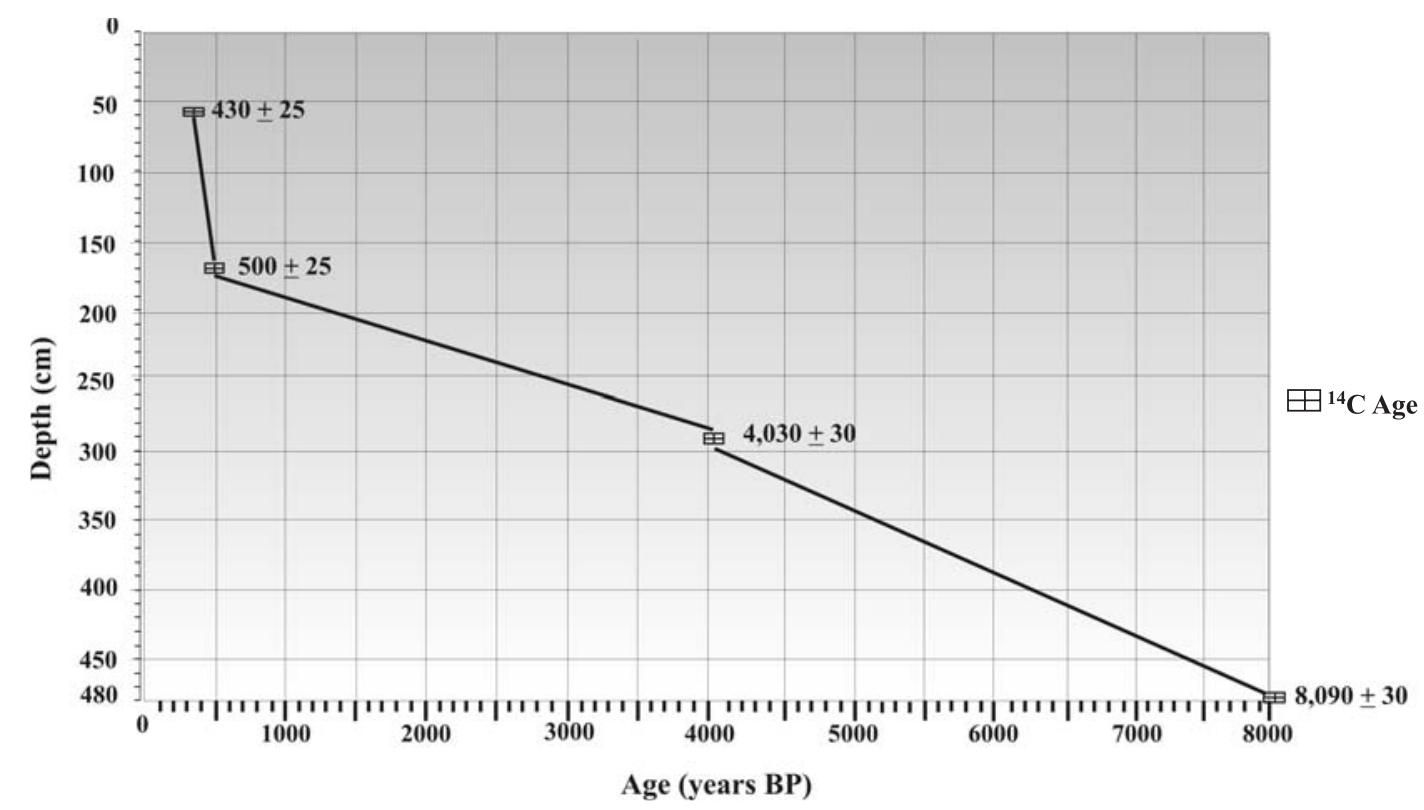

Figure 3. Determined and interpolated ${ }^{14} \mathrm{C}$ ages of layers of the peatland profile from Pau-de-Fruta SPA. 
$\mathrm{Hd}_{2}$ to $\mathrm{Hd}_{6}( \pm 1,200$ to $\pm 5,800$ years $\mathrm{BP}$ - interpolated ages) and 405-430 $\mathrm{cm}$ horizon $\mathrm{Hd}_{7}( \pm 6,700$ to \pm 6,500 years BP - interpolated ages). This suggests drier/less wet conditions with the incidence of paleofire during the formation of this peatland (Pessenda et al., 1998). Sand deposition indicates interruption of organic matter accumulation (Turcq et al., 2002).

\section{Morphological and physical properties}

The correlation coefficients between evaluated properties and their significances are presented in table 2.

The color in the sodium pyrophosphate extract varied from black (10YR 2/1) to dark-yellowish-brown (10YR 4/4). Lighter colors were observed near the soil surface (layers 0-60 and 137-244 cm), while darker colors were found near the base $(244-505 \mathrm{~cm})$. The correlation between color and von Post scales showed a value of 0.68 (Table 2), indicating that the color shading is related to the level of chemical decomposition with depth (Dengiz et al., 2009).

Three stages of organic matter decomposition were observed according to the scales of von Post (Figure 2): most decomposed material (sapric - Hd horizon) near the base (202-475 cm), intermediate material (hemic - Hod and Hdo horizons) at 40-187 cm and poorlydecomposed material (fibric - Ho horizon) in the $30 \mathrm{~cm}$ surface layer, consistent with the Superposition Principle (unidirectional evolution - Hamblin, 1978) of overlayering of the older by the most recent material. The correlation between $\mathrm{RF}$ and von Post was -0.818 , and 0.805 between von Post and MM (Table 2), indicating lower fiber content and greater contributions of mineral material, respectively in soil samples at an advanced decomposition stage.

High contents of RF (Figure $4 \mathrm{a}$ ) and $\mathrm{Gm}$ (Figure $4 \mathrm{~b})$ occurred in fibric $(0-60 \mathrm{~cm})$ and hemic horizons (137-187 cm and 196-202 cm), indicating that the plant remains were still in the initial process of decomposition. The structure was preserved and the water flow greater, due to the higher number of macropores. Another factor possibly related to the number of fibers is the type of vegetation that contributes to the formation of soil organic matter (White II et al., 2009), which will be discussed together with the $\delta^{13} \mathrm{C}$ isotopic signals.

The more viscous consistency of sapric horizons (190-196 cm and 202-475 cm) is due to the advanced stage of decomposition of the samples. In some cases, the contribution of algae in wetter periods, e.g., gyttjas of swamps and lake sediments, also leads to this consistency (Foster \& Fritz, 1987). In general, roots and/or plant fragments, charcoal fragments and intercalation with sand deposits were observed in the more decomposed material, suggesting that this material was formed under alternating wet and dry conditions.

The MR and MM values increased with soil depth (Figure 4c,d). The correlation between these properties was 0.706 , while the correlations between $\mathrm{RF}$ and $\mathrm{MM}, \mathrm{Gm}$ and $\mathrm{MR}$ and $\mathrm{OM}$ and $\mathrm{MR}$ were -0.592, -0.894 and -0.782 , respectively. The presence of mineral material may be related to the mineralization of soil organic matter, reducing OM quantity, and/or to the climate causing interruption of organic sedimentation under drier conditions.

Despite the homogeneity of Omd (Figure 4e), an abrupt change was observed between the values of surface soils and soils at the bottom of the water layer, with respective values of $0.025 \mathrm{Mg} \mathrm{m}^{-3}$ in $50-60 \mathrm{~cm}$ (sample 6 of Ho horizon) and $0.247 \mathrm{Mg} \mathrm{m}^{-3}$ in 137$147 \mathrm{~cm}$ (sample 7 of Hod horizon). According to Clymo (1992), this higher density can be observed after a collapse of the material below the horizon with greater water flow.

Table 2. Coefficients of simple correlation (Pearson analysis) compared to the association degree of the determined properties

\begin{tabular}{|c|c|c|c|c|c|c|c|c|}
\hline & Color & von Post & RF & Gm & MM & MR & Omd & pH \\
\hline & & & & $\%$ & - & $\mathrm{m} \mathrm{m}^{-1}$ & $\mathrm{Mg} \mathrm{m}^{-3}$ & \\
\hline $\begin{array}{l}\text { Color }^{(1)} \\
\text { von Post }\end{array}$ & $.681^{* *}$ & & & & & & & \\
\hline $\mathrm{RF}^{(3)}$ & $-.518^{* *}$ & $-.818^{* *}$ & & & & & & \\
\hline $\mathrm{Gm}^{(4)}$ & $-.399^{* *}$ & $-.645^{* *}$ & $.440^{* *}$ & & & & & \\
\hline $\mathrm{MM}^{(5)}$ & $.589^{* *}$ & $.805^{\text {** }}$ & $-.592^{* *}$ & $-.549^{* *}$ & & & & \\
\hline $\mathrm{MR}^{(6)}$ & $.378^{*}$ & $.684^{* *}$ & $-.457^{* *}$ & $-.894^{* *}$ & $.706^{* *}$ & & & \\
\hline $\mathrm{Omd}^{(7)}$ & $\mathrm{ns}$ & $\mathrm{ns}$ & ns & $\mathrm{ns}$ & $\mathrm{ns}$ & & & \\
\hline $\mathrm{pH}^{(8)}$ & ns & $\mathrm{ns}$ & $\mathrm{ns}$ & $-.436^{\text {** }}$ & $.304^{*}$ & $.497^{* *}$ & $\mathrm{~ns}$ & \\
\hline $\mathrm{OM}^{(9)}$ & $-.585^{* *}$ & $-.799^{* *}$ & $.590^{* *}$ & $.823^{* *}$ & $-.829^{* *}$ & $-.782^{* *}$ & $.436^{* *}$ & $-.392^{* *}$ \\
\hline
\end{tabular}

(1) Color: Color by sodium Pyrophosphate $\left(\mathrm{Na}_{2} \mathrm{P}_{2} \mathrm{O}_{7}\right) .{ }^{(2)}$ von Post: Classes referring to the von Post scale of decomposition. ${ }^{\left({ }^{(3)}\right.} \mathrm{RF}$ : Rubbed fibers. ${ }^{(4)} \mathrm{Gm}$ : Gravimetric moisture. ${ }^{(5)} \mathrm{MM}$ : Mineral material. ${ }^{(6)}$ MR: Minimal residue. ${ }^{(7)}$ Omd: Organic matter density of. ${ }^{(8)} \mathrm{pH}: \mathrm{pH}$ in $\mathrm{CaCl}_{2} \cdot{ }^{(9)} \mathrm{OM}$ : Organic matter. ns: non-significant. 

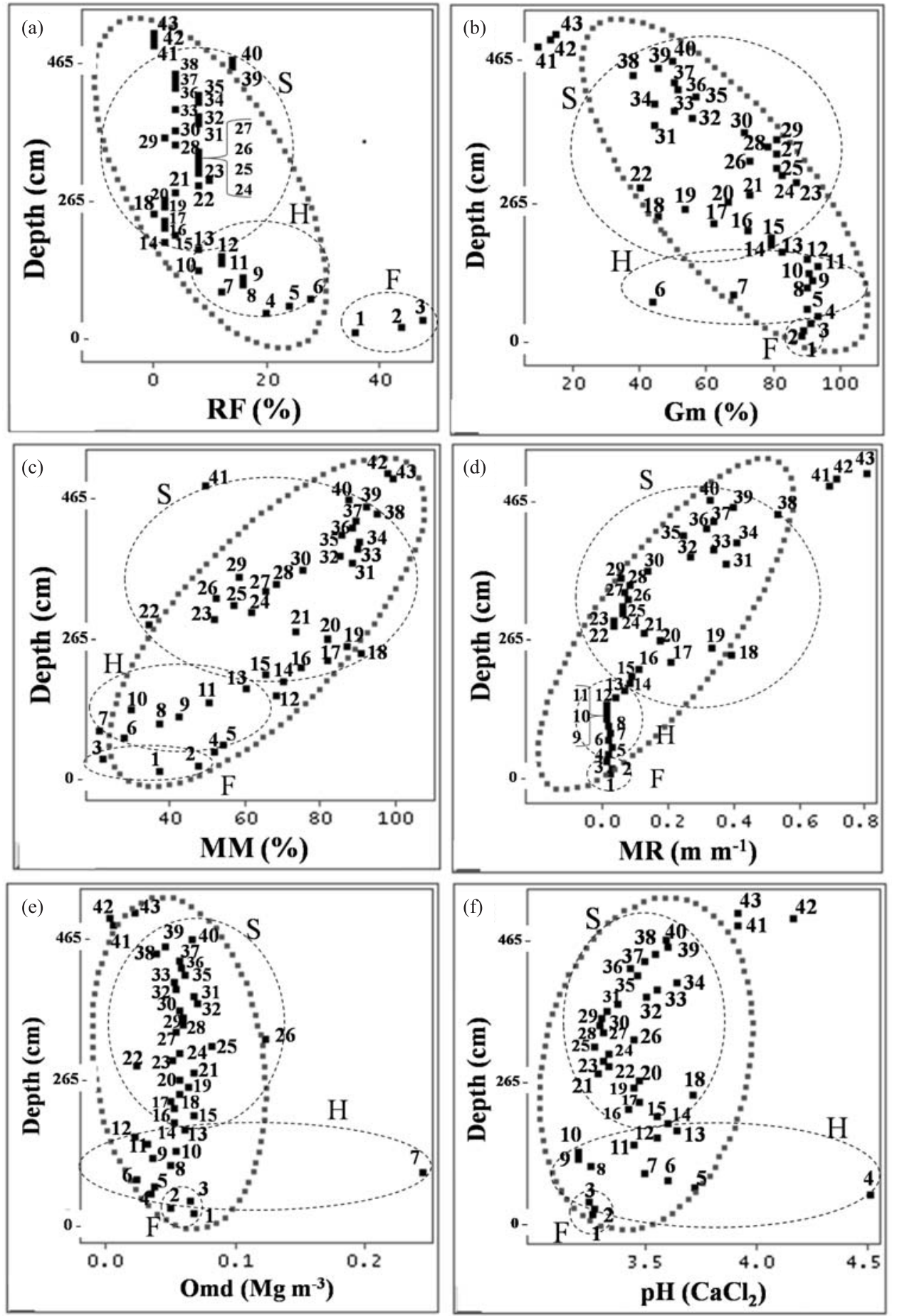

Figure 4. Depth distribution of properties of a profile of the peatland from Pau-de-Fruta SPA. RF: Rubbed fibers. Gm: Gravimetric humidity. MM: Mineral material. MR: Minimal residue. Omd: Organic matter density. pH: in $\mathrm{CaCl}_{2}$. F: Fibric. H: Hemic. S: Sapric.

\section{Chemical properties}

Analyses of $\mathrm{pH}$ in $\mathrm{CaCl}_{2}$ (Figure $4 \mathrm{f}$ ) indicate a highly acidic soil (between 3.20 in $157-177 \mathrm{~cm}$, in samples 9 and 10, Hod horizon; and 4.52 in $30-40 \mathrm{~cm}$, sample 4, Ho horizon), leading to slow decomposition of organic matter. These values corroborate the findings of other studies (Horák et al., 2007; Silva et al., 2008; Campos, 2009) for the Histosols of the Mountain Range of the Espinhaço Meridional. The $\mathrm{pH}$ in the collection tube was less acidic (Figure 5a), with values near 5.00 , except in $70-75 \mathrm{~cm}$, where the 

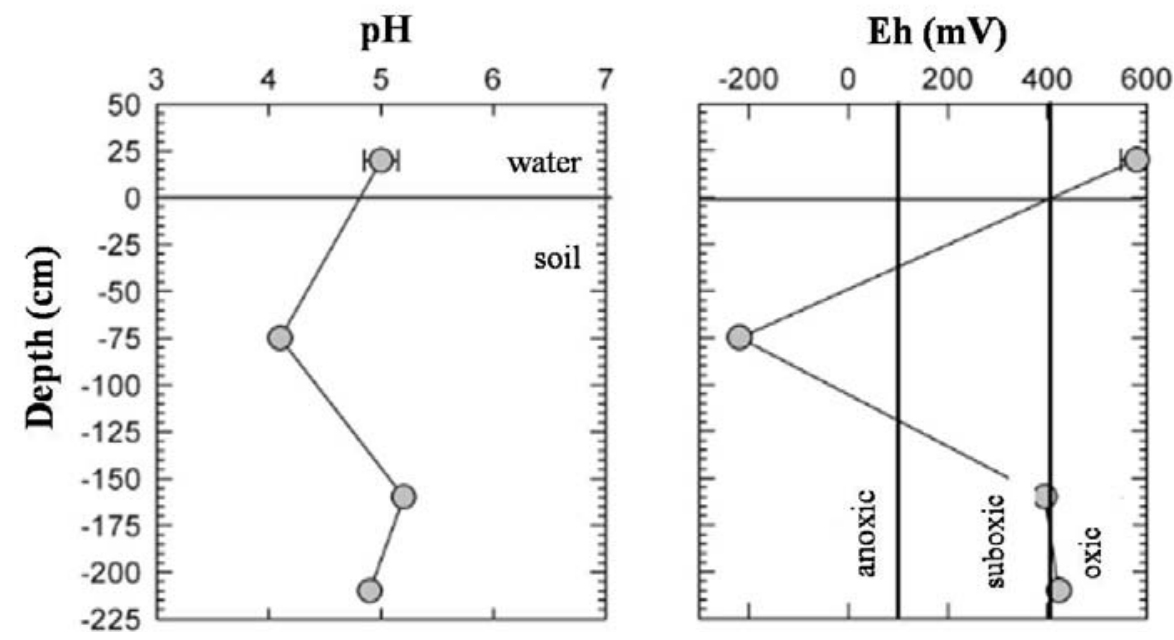

Figure 5. Values of $\mathrm{pH}$ and potential redox $(\mathrm{Eh})$ of the peatland profile from Pau de-Fruta SPA.

water layer is found, with a value close to 4.00. Despite the high acidity, the behavior of the redox potential (Figure 5b) was anomalous and varied considerably with depth, shifting from oxic conditions at the surface to strongly reduced (anoxic) in 70-75 cm, returning to a strong increase near oxic conditions in 150 $200 \mathrm{~cm}$.

The OM content in the organic material ranged from $78.78 \mathrm{~g} \mathrm{~kg}^{-1}$ in $137-147 \mathrm{~cm}$ (Hdo horizon) to $4.84 \mathrm{~g} \mathrm{~kg}^{-1}$ in $445-455 \mathrm{~cm}\left(\mathrm{Hd}_{7}\right.$ horizon), and highest levels were found in the fibric and hemic horizons. The average OM content in mineral horizons was $0.84 \mathrm{~g} \mathrm{~kg}^{-1}$ (C and $2 \mathrm{C}$ horizons), consistent with the high levels of MM and MR. A sharp increase was observed above (50-60 cm - Ho horizon) and below (137-147 cm - Hod horizon) the water layer from 22.03 to $78.78 \mathrm{~g} \mathrm{~kg}^{-1}$, which corroborates the structural model of peatlands proposed by Clymo (1992), with OM accumulation at the bottom of the collapsed layer.

\section{Integration of characterized properties}

The Principal Component Analysis (PCA) showed the properties that may have contributed most to the formation of this peatland and which best explained the characteristics of Histosols in the study. The eigenvalues of the first two principal components showed most variation, with a cumulative value of $72 \%$. The first principal component (PCR1) explained $53.4 \%$ of data variation, which was directly attributable to $\mathrm{pH}$ values and $\mathrm{MR}$ and inversely to the values of RF and OM (shown by samples 41, 42 and 43, and 1, 2 and 3, respectively, in Figure 6). Likewise, the second principal component (PCR2) explained $18.6 \%$ of the attribute variability, where Omd and von Post (samples 21, 29, 30) were directly related to data variations, while $\mathrm{pH}$ and $\mathrm{MR}$ (samples 41, 42 and 43) were inversely related (Figure 6). Samples with PCR1 and PCR2 values near 0.0 were not relevant to explain the data variation.
Each reference line corresponds to the 11 properties that characterize Histosols, according to SiBCS (Embrapa, 2006) (Figure 6), and differences in the length of straight lines are reflexes of greater or lesser contribution to the formation of this soil, thus corroborating the determination of properties that most explained PCR1 and PCR2, given that RF and MR had the greatest length.

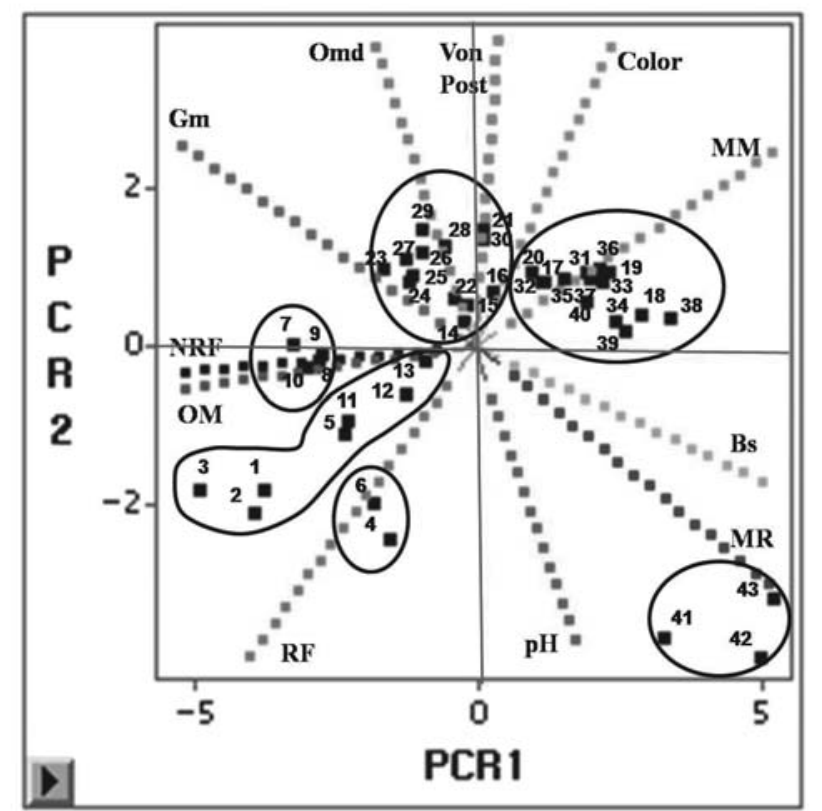

Figure 6. Grouping of samples collected in the study, based on the analysis of principal components. RF: Rubbed fiber content. OM: Organic matter. URF: Unrubbed fiber content. Gm: Gravimetric humidity. Omd: Organic matter density. von Post: classes referring to the von Post scale of decomposition. Color: color by sodium Pyrophosphate. MM: Mineral material. Bs: Soil density. MR: Minimal residue. $\mathrm{pH}$ : in $\mathrm{CaCl}_{2}$. 
In the horizons near the surface $(0-60$ and $137-$ $202 \mathrm{~cm}$, samples 1 to 13) the values of OM, URF and $\mathrm{RF}$ were high. Three groups were distinguished (Figure 6), primarily related to the latest developmental stages in the soil, that is, fibric and hemic. The absence of plant fragments in these layers suggests the absence or little contribution of woody vegetation to the peatland, and a predominance of herbaceous-graminoid material (Figueiral et al., 1999).

The depth intervals 202-235 cm of the $\mathrm{Hd}_{2}$ and $\mathrm{Hd}_{3}$ horizons (samples 14 to 16 ) and $274-375 \mathrm{~cm}$ of $\mathrm{Hd}_{5}$ and $\mathrm{Hd}_{6}$ horizons (samples 21-30), corresponding to the periods between $\pm 1,000$ to $\pm 2,300$ years BP and $\pm 3,500$ to $\pm 5,700$ years BP (interpolated age), respectively, were grouped according to $\mathrm{Gm}, \mathrm{Omd}$ and decomposition classes of von Post. These sapric horizons were possibly originated under wetter conditions than the present, since, aside from the very viscous consistency, no sand deposition was observed (Figure 2).

Plant fragments indicate woody vegetation and charcoal fragments suggest that despite the prevailing moist periods, there were short drier times, when the occurrence of fires caused more carbonization of tree and/or shrub species. Overall, the Omd values were high allowing to infer the presence of vegetation with high contribution to soil organic matter, possibly herbaceous/graminoid co-existing with woody vegetation (forest). Other sources that possibly contributed were the microscopic aquatic organisms in freshwater, the phytoplankton, in view of the very viscous soil consistency in these layers. Therefore, it was inferred that the vegetation of the horizons in these depth intervals was mixed, with trees (forest) as well as herbaceous species (field), besides a possible phytoplankton contribution, under a wetter climate interspersed with dry weather.

Near the profile base, the sapric layers in 235$274 \mathrm{~cm}$ of horizon $\mathrm{Hd}_{4}$ (samples 17 to 20) and 375$475 \mathrm{~cm}$ of horizon $\mathrm{Hd}_{7}$ (samples 31 to 40), respectively, corresponding to periods at $\pm 2,300$ to $\pm 3,500$ years $\mathrm{BP}$ and $\pm 5,700$ to $\pm 8,000$ years $\mathrm{BP}$ (interpolated age) were grouped mainly according to the high levels of MM in the soil, and this contribution was attributed to the presence of dry conditions in these periods, in agreement with sand deposition observed in the description profile of the Histosols in this study (Figure 2), and/or to high frequency of winds, which could have dragged and deposited material of sandy soils in the downstream area of the Pau-de-Fruta Special Protection Area - SPA. The plant and charcoal fragments, indicators of woody vegetation, are interspersed with sand deposition, suggesting continual fluctuations of wetter and drier periods than today.

The isolated grouping of depth intervals of $\mathrm{C}$ and $2 \mathrm{C}$ mineral horizons (samples 41 to 43 ) was related to high proportions of MR. Therefore, it appears that before the establishment of the formation conditions of the Histosol under study, before 8,090 \pm 30 years $\mathrm{BP}\left({ }^{14} \mathrm{C}\right.$ age $)$, there was some event or condition which prevented the accumulation of organic material, i.e., impaired the existence and development of vegetation under and around the peatland. This event probably removed the surface soil, possibly due to a wetter climate condition than today, since the predominance of mineral material (high MR values) indicates the presence of a fluvial system. Sediment profiles in Cerrado areas, such as the Lake Carajás (PA) (Absy et al., 1991) and Lagoa da Serra Negra (MG) (De Oliveira, 1992), also indicate the occurrence of very wet weather during the period near the formation of the peatland under study.

\section{Trends in the development of soil organic matter sources}

In general, TOC, $\mathrm{N}$ and $\delta^{13} \mathrm{C}$ values increased from bottom to surface of the peat core, while the $\mathrm{C} / \mathrm{N}$ ratio decreased and the ${ }^{15} \mathrm{~N}$ values oscillated constantly (Figure 7).

In the $2 \mathrm{C}$ horizon, before $8,090 \pm 30$ years $\mathrm{BP}\left({ }^{14} \mathrm{C}\right.$ age), the high $\mathrm{C} / \mathrm{N}$ ratio of 47.67 at $505-496 \mathrm{~cm}$ indicates a strong contribution of $\mathrm{C}_{3}$ terrestrial plants, while the absolute zero at 496-486 cm indicates great influence of freshwater phytoplankton, corroborated by the high $\delta^{15} \mathrm{~N}$ value observed in the profile (Meyers, 1994) $+7.63 \%$, and the lowest TOC values, $0.02 \mathrm{~g} \mathrm{~kg}^{-1}$. Among terrestrial plants, the average $\delta^{13} \mathrm{C}$ signal of $22.66 \%$ at $2 \mathrm{C}$ horizon suggests the contribution of the $\mathrm{C}_{3}$ and $\mathrm{C}_{4}$ mixture, and the possible presence of plants from the CAM cycle.

Significant oscillations of $\mathrm{C} / \mathrm{N}$ ratios were observed at 505-300 $\mathrm{cm}$ (horizons $2 \mathrm{C}, \mathrm{C}$, and $\mathrm{Hd}_{7}$ to $\mathrm{Hd}_{5}$ ), for the periods $8,090 \pm 30$ years $\mathrm{BP}\left({ }^{14} \mathrm{C}\right.$ age $)$ and \pm 4,100 years BP (interpolated age), with maximum value of 57.08 at $475-465 \mathrm{~cm}$ and minimum of zero in $496-486 \mathrm{~cm}$, as previously stated. These variations are a reflection of moisture fluctuations, resulting in alternate expansion and retraction of $\mathrm{C}_{3}$ terrestrial plants and aquatic organisms. In the same period, $\delta^{13} \mathrm{C}$ signals also oscillated, in which increased values as observed in 435-425 cm with - $24.75 \%$ occurred amidst reduced signals, as $-26.41 \%$ at $405-395 \mathrm{~cm}$ suggesting short, possibly less humid periods, in which charred fragments (natural causes) and significant sand content (MM and MR levels) were also found.

The high $\mathrm{C} / \mathrm{N}$ ratios with reduced $\delta^{13} \mathrm{C}$ signals, very viscous soil consistency, presence of plant fragments and few fibers are evidence of a wetter environment in the Early/Middle Holocene (8,0904,100 years $\mathrm{BP}$ ), with major contribution of $\mathrm{C}_{3}$ plants possibly more tree than herbaceous. The increase in TOC and $\mathrm{N}$ are associated with a higher contribution to sources of organic matter.

After $\pm 4,100$ years $\mathrm{BP}$ until $\pm 2,500$ years $\mathrm{BP}$ (interpolated age), in $300-224 \mathrm{~cm}$ (horizons $\mathrm{Hd}_{5}$ to $\mathrm{Hd}_{2}$ ), the $\mathrm{C} / \mathrm{N}$ ratio values were lower and more 


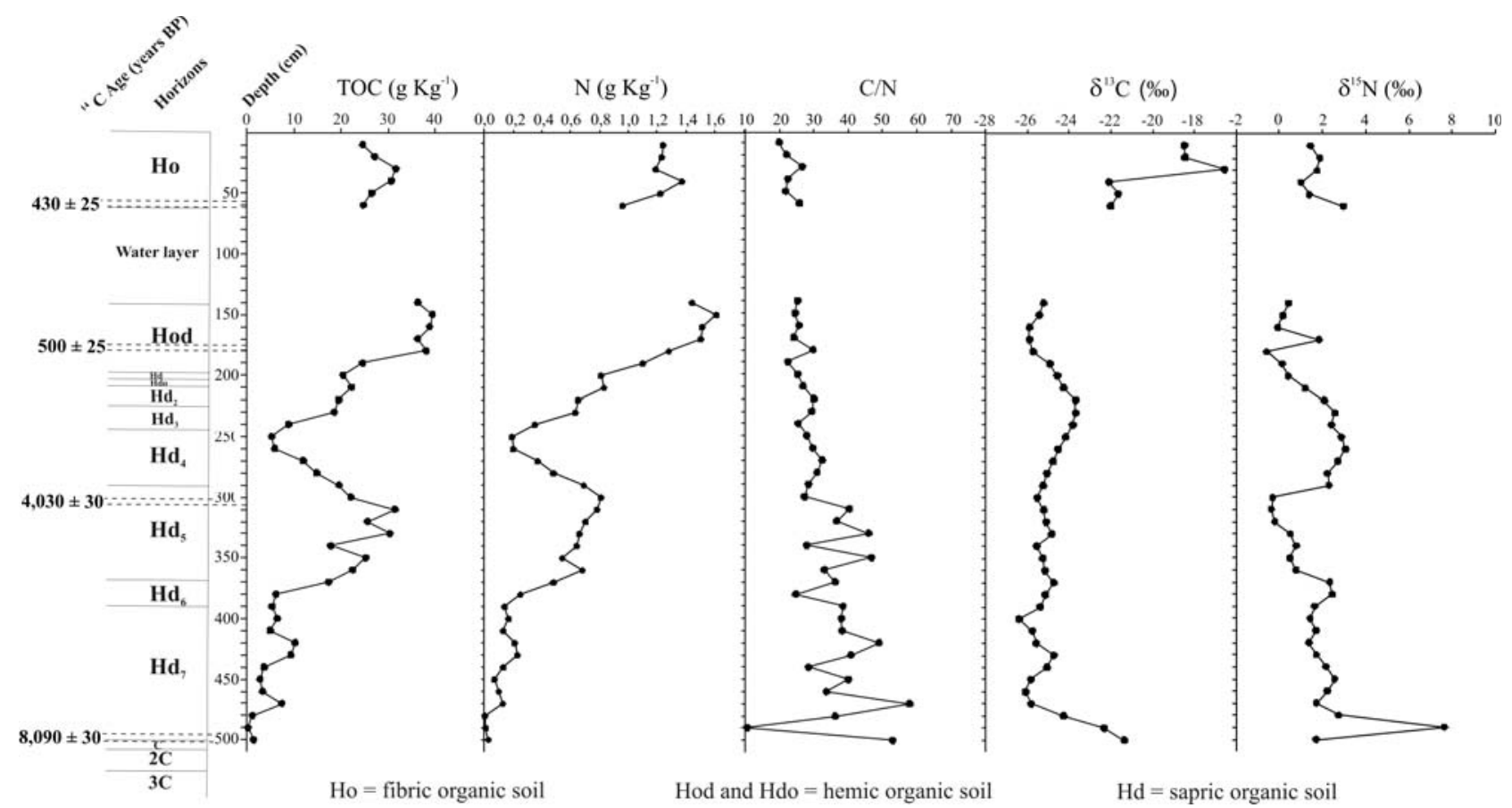

Figure 7. Distribution of TOC, N, C/N, $\delta^{13} \mathrm{C}$ and $\delta^{15} \mathrm{~N}$ contents in depth in the profile of the peatland from Paude-Fruta SPA.

constant than in past ages, ranging from 39.98 to 25.40 , respectively, in $289-284 \mathrm{~cm}$ and $244-235 \mathrm{~cm}$. Signals of $\delta^{13} \mathrm{C}$ and $\delta^{15} \mathrm{~N}$ increased, , respectively, to $-23.70 \%$ in $235-224 \mathrm{~cm}$ and $3.06 \mathrm{~cm}$ in $264-254$. These data allow the conclusion that the $\mathrm{C}_{4}$ plants increased, featuring a greater influence of field vegetation, besides the increase of phytoplankton influence, characterizing a swampy environment, despite the reduction in moisture content. The less humid climate is also evidenced by the observations of sand deposition at $257 \mathrm{~cm}\left(\mathrm{Hd}_{4}\right.$ horizon) and the high MR and MM values. Between 2,500-2,000 years $\mathrm{BP}$, a global climate event known as the Iron Age occurred, which is the coldest period of the interglacial period (Sant'anna Neto \& Nery, 2005), and possibly contributed to drying the climate in some regions, e.g., the study area.

The $\mathrm{C} / \mathrm{N}$ ratio continued with the same pattern compared to the previous conditions between \pm 2,500 years BP and approximately 500 years BP, at 224-137 cm ( $\mathrm{Hd}_{2}$, Hdo, $\mathrm{Hd}$, and Hod horizons), suggesting the stabilization of organic matter compounds. Signals of $\delta^{13} \mathrm{C}$ decreased, reaching $-25.92 \%$ at $177-172 \mathrm{~cm}$, indicating a gradual return of $\mathrm{C}_{3}$ plants. The increase in TOC and $\mathrm{N}$ values reached $39.45 \mathrm{~g} \mathrm{~kg}^{-1}$ and $1.61 \mathrm{~g} \mathrm{~kg}^{-1}$, in $157-147 \mathrm{~cm}$, respectively, suggesting the increase of Campo Úmido vegetation, since no woody fragments were observed.

After 430 years BP ( ${ }^{14} \mathrm{C}$ age), at $60-50 \mathrm{~cm}$ (Ho horizon), values of TOC, N, C/N, $\delta^{13} \mathrm{C}$ and $\delta^{15} \mathrm{~N}$ increased, following the trend observed in the depth intervals below the water layer. The increase in occupancy rate of the area of $\mathrm{C}_{4}$ plants was observed in 30-20 cm, since an isotopic signal of - $16.55 \%$ was observed, and the values of TOC and $\mathrm{N}$ were high as well. In \pm 200 years BP (in $30-20 \mathrm{~cm}$ ), a period equivalent to the year $1,750 \mathrm{AD}$, the planet experienced a little glacial age (Little Ice Age), a very cold and harsh period in Europe, with temperatures of $2-3{ }^{\circ} \mathrm{C}$ lower than today (Sant'anna Neto \& Nery, 2005), along with dry conditions in the southern hemisphere (Hendy et al., 2002). Therefore, the climate in this period was possibly drier than today, with greater contribution of the dry field vegetation, in which high $\mathrm{RF}$ levels of fibric horizon confirm this type of vegetation.

After this dry (or less humid) event up to $10-0 \mathrm{~cm}$, $\delta^{13} \mathrm{C}$ values suffered a slight reduction, reaching $-18.48 \%$ at the top of the profile, characteristic of the mixture of $\mathrm{C}_{3}$ and $\mathrm{C}_{4}$ plants and possible CAM. The values of TOC, $\mathrm{N}$ and $\mathrm{C} / \mathrm{N}$, respectively $24.64 \mathrm{~g} \mathrm{~kg}^{-1}$, $1.24 \mathrm{~g} \mathrm{~kg}^{-1}$ and 19.87 , indicate a strong contribution of grasses and herbaceous plants, both $\mathrm{C}_{3}$ and $\mathrm{C}_{4}$, and CAM, besides the influence of phytoplankton and trees of the current Capões forests of the Semidecidual Seasonal Forest.

\section{CONCLUSIONS}

1. The Histosol of Pau-de-Fruta Special Protection Area - SPA was characterized as sapric, which corresponds to a deposit in a stage of highly advanced pedogenic evolution. 
2. The predominant vegetal cover in the peatland at the beginning of its formation may have been predominantly herbaceous. In the Early/Middle Holocene, between 8,090 and 4,100 years BP, the tree cover may have been more significant, indicating more humid periods than today. In the Late Holocene from 2,500 years BP until 430 years BP, the herbaceous/ graminoid vegetation may have expanded again and the tree cover may have regressed. After 430 years $\mathrm{BP}$, the climate may become more humid, as the current one.

\section{ACKNOWLEDGEMENTS}

We give thanks to the São Paulo Research Foundation - FAPESP for granting the scholarship to the first author, and to Companhia de Saneamento de Minas Gerais (COPASA), for granting authorization to enter and study the Pau-de-Fruta Special Protection Area - SPA (Pau-de-Fruta/Diamantina EPA) and to allow the prospection of the studied profile.

\section{LITERATURE CITED}

ABSY, M.L.; CLEEF, A.; FOURNIER, M.; MARTIN, L.; SERVANT, M.; SIFFEDINE, A..; FERREIRA SILVA, M.; SOUBIÈS, F.; SUGUIO, K.; TURCQ, B. \& van der HAMMEN, T. Mise en évidence de quatre phases dóuverture de la forêt dense dans le sud-est de l'Amazonie $\mathrm{au}$ tours des. 60000 dernières années. Première comparación avec d'autre régions tropicales. Comptes Rendus l’Académie Sci., 312:673-678, 1991.

BARBER, K.E. Peat stratigraphy and climatic change: A palaeoecological test of the theory of cyclic peatland regeneration. Rotterdam, Balkema, 1981. 220p.

BERTAUX, J.; LEDRU, M.-P.; SOUBIÈS, F. \& SONDAG, F. The use of quantitative mineralogy linked to palynological studies en palynological reconstruction: The case study of the "Lagoa Campestre" lake, Salitre, Minas Gerais, Brazil. Compte Rendus l’Academie Sci., 323:65-71, 1996.

BOATMAN, D.J. \& TOMLINSON, R.W. The silver flowe I. Some structural and hidrological features of brishie bog and their bearing on pool formation. J. Ecol., 61:653-666, 1973.

CAMPOS, J.R.R. Caracterização, mapeamento, volume de água e estoque de carbono da turfeira da Área de Proteção Ambiental Pau-de-Fruta. Diamantina, Universidade Federal dos Vales do Jequitinhonha e Mucuri, Minas Gerais, 2009. 101p. (Tese de Mestrado)

CLYMO, R.S. Productivity and decomposition of peatland ecosystems. In: BRAGG, O.M.; HULE, P.D.; INGRAM, H.A.P. \& ROBERTSON, R.A., eds. Peatland ecosystems and man: An impact assessment. Dundee, Inter. Peat Society, 1992. p.3-16.
DE OLIVEIRA, P.E. A palynological record of late quaternary vegetacional and climatic change in Southeastern Brazil. Columbus, Ohio State University, 1992. 242p. (Tese de Doutorado)

DENGIZ, O.; OZAYTEKIN, H.; CAYCI, G. \& BARAN, A. Characteristics, genesis and classification of a basin peat soil under negative human impact in Turkey. Environ. Geol., 56:1057-1063, 2009.

EMPRESA BRASILEIRA DE PESQUISA AGROPECUÁRIA EMBRAPA. Centro Nacional de Pesquisa de Solos. Sistema brasileiro de classificação de solos. 2.ed. Rio de Janeiro, 2006. 306p.

FIGUEIRAL, I.; MOSBRUGGER, V.; ROWE, N. P.; ASHRAF, A. R.; UTESCHER, T. \& JONES, T.P. The Miocene peatforming vegetation of northwestern Germany: An analysis of wood remains and comparison with previous palynological interpretations. Rev Palaeobot Palynol., 104:239-266, 1999

FITZPATRICK, R.W.; RAVEN, M.D. \& FORRESTER, S.T. A systematic approach to soil forensics: Criminal case studies involving transference from crime scene to forensic evidence. In: KARL, R.; LORNA, D. \& DAVID, M. Criminal and environmental soil forensics. Dordrecth, Springer, 2009. p.105-127.

FOSTER, D.R. \& FRITZ, S.C. Mire development, pool formation and landscape processes on patterned Fens in Dalarna, central Sweden. J. Ecol., 75:409-437, 1987.

HAMBLIN, K.K.; PROVO, B.Y.U.; ILLUS, U.T.; CHESSER, W.L. \& TASA, D. The earth's dynamic systems, a textbook in physical geology. Mineapolis, Burgess Publishing Company, 1978. p.115.

HENDY, E.J.; GAGAN, M.K.; ALIBERT, C.A.; McCULLOCH, T.; LOUGH, J.M. \& ISDALE, P.J. Abrupt decrease in tropical pacific sea surface salinity at end of little ice age. Science, 295:1511-1514, 2002.

HORÁK, I.; SILVA A.C.; FERREIRA C.A.; RODRÍGUEZ RACEDO J.; MARTÍNEZ CORTIZAS A.; SILVA E.B. \& GRAZZIOTTI P.H. Turfeiras da Serra do Espinhaço Meridional - MG: I - caracterização morfológica, física, química e microbiológica. In: CONGRESSO BRASILEIRO DE CIÊNCIA DO SOLO, 26., Gramado, 2007. Anais... Gramado, Sociedade Brasileira de Ciência do Solo, 2007. CD-ROM.

INSTITUTO BRASILEIRO DE GEOGRAFIA E ESTATÍSTICA - IBGE. Manuais técnicos em geociências. 2.ed. Rio de Janeiro, 2005. 300p.

JIANLI, W.; XIAOMIN, F. \& JIJUN, L. Eolian sand deposition and its environmental significance in the northeastern margin of the Qinghai-Xizang Plateau. Chin. Sci. Bull., 44:2250-2255, 1999.

LEDRU, M.-P.; BRAGA, I.S.B.; SOUBIÈS, F.; FOURNIER, M.; MARTIN, L.; KENITIRO, S. \& TURCQ, B. The last 50,000 years in the Neotropics (Southern Brazil): Evolution of vegetation and climate. Palaeogeogr. Palaeocl., 123:239$257,1996$.

MARTIN, L.; FLEXOR, J.M. \& SUGUIO, K. Vibrotestemunhador leve: Construção, utilização e possibilidades. R. IG, 16:5966, 1995. 
MAUQUOY, D. \& YELLOFF, D. Raised peatland development and possible responses to environmental changes during the mid- to late-Holocene. Can the palaeoecological record be used to predict the nature and response of raised peatlands to future climate change? Biodivers. Conserv., 17:2139-2151, 2008

MEYERS, P.A. Preservation of source identification of sedimentary organic matter during and after deposition. Chem. Geol., 144:289-302, 1994.

NEVES, S.C.; ABREU, P.A.A. \& FRAGA, L.M.S. Fisiografia. In: SILVA, A.C.; PEDREIRA, L.C.V.S.F. \& ABREU, P.A.A. Serra do Espinhaço Meridional: Paisagens e ambientes. Belo Horizonte, O Lutador, 2005. p.47-58.

PESSENDA, L.C.R.; GOMES, R.; ARAVENA, R.; RIBEIRO, A.S.; BOULET, R. \& GOUVEIA, S.E.M. The carbon isotope record in soils along a forest-cerrado ecosystem transect: Implications for vegetation changes in the Rondonia State, Southwestern Brazilian Amazon Region. Holocene, 8:599-603, 1998.

PESSENDA, L.C.; RIBEIRO, A.S.; GOUVEIA, S.E.M.; ARAVENA, R.; BOULET, R. \& BENDASSOLLI, J.A. Vegetation dynamics during the late Pleistocene in the Barreirinhas region, Maranhão State, northeastern Brazil, based on carbon isotopes in soil organic matter. Quatern. Res., 62:183-193, 2004.

PESSENDA, L.C.R.; LEDRU, M-P.; GOUVEIA, S.E.M.; ARAVENA, R.; RIBEIRO, A.S.; BENDASSOLLI, J.A. \& BOULET, R. Holocene palaeoenvironmental reconstruction in northeastern Brazil inferred from pollen, charcoal and carbon isotope records. Holocene, 15:814$822,2005 b$

PETERSON, B.J. \& HOWARD, R.W. Sulfur, carbon, and nitrogen isotopes used to trace organic matter flow in the salt-marsh estuaries of Sapelo Island, Georgia. Limnol. Oceanogr., 32:1195-1213, 1987.

RIBEIRO, J.F. \& WALTER, B.M.T. Fitofissionomias do bioma do Cerrado. In: SANO, S.M. \& ALMEIDA, S.P, eds. Cerrado: ambiente e flora. Planaltina, Empresa Brasileira de Pesquisa Agropecuária, 1998. p.89-166.

SALGADO-LABOURIAU, M.L. Critérios e técnicas para o quaternário. São Paulo, Edgard Blücher, 2007. 387p.

SANT'ANNA NETO, J.L. \& NERY, J.T. Variabilidade e mudanças climáticas no Brasil e seus impactos regionais. In: DE OLIVEIRA, P.E.; SUGUIO, K. \& GOUVEIA, C., orgs. Quaternário do Brasil. Ribeirão Preto, Holos, 2005. p.28-51.
SANTOS, R.D.; LEMOS, R.C.; SANTOS, H.G.; KER, J.C. \& ANJOS, L.H.C. Manual de descrição e coleta de solo no campo. 5.ed. Viçosa, MG, Sociedade Brasileira de Ciência do Solo, 2005. 100p.

SILVA, E.B.; SILVA, A.C.; GRAZZIOTTI, P.H.; FARNEZZI, M.M.M.; FERREIRA, C.A.; COSTA, H.A.H. \& HORAK, I. Comparação de métodos para estimar a acidez potencial mediante determinação do $\mathrm{pH}$ SMP em Organossolos da Serra do Espinhaço Meridional. R. Bras. Ci. Solo, 32:20072013, 2008.

SPIELHAGEN, R. \& TRIPATI, A. Evidence from svalbard for near-freezing temperatures and climate oscillations in the arctic during the paleocene and eocene. Palaeogeogr. Palaeoclimatol. Palaeoecol., 278:48-56, 2009.

STANEK, W. \& SILC, T. Comparisons of four methods for determination of degree of peat humification (decomposition) with emphasis on the von post method. Canadian J. Soil Sci., 57:109-117, 1977.

TALBOT, M.R. \& JOHANNESSEN, T. A high resolution paleoclimatic record for the least 27,500 years in tropical West Africa from the carbon and nitrogen isotopic composition of lacustrine organic matter. Earth Planet. Sci. Lett., 100:23-37, 1992.

TURCQ, B.; ALBUQUERQUE, A.L.S.; CORDEIRO, R.C.; SIFEDDINE, A.; SIMOES FILHO, F.F.L.; SOUZA, A.G.; ABRÃO, J.J.; OLIVEIRA, F.B.L.; SILVA, A.O. \& CAPITÂNEO, J. Accumulation of organic carbon in five brazilian lakes during the holocene. Sediment. Geol., 148:319-342, 2002

VELOSO, H.P.; RANGEL FILHO, L.R. \& LIMA, J.C.A. Classificação da vegetação brasileira adaptada a um sistema universal. Rio de Janeiro, Instituto Brasileiro de Geografia e Estatística, 1991. 123p.

VELOSO H.P. Manual técnico da vegetação brasileira. Rio de Janeiro, Instituto Brasileiro de Geografia e Estatística, 1992. 92p.

WHITE II, D.A.; WELTY-BERNARD, A.; RASMUSSEN, C. \& SCHWARTZ, E. Vegetation controls on soil organic carbon dynamics in an arid, hyperthermic ecosystem. Geoderma, 150:214-223, 2009. 